Charnock, David and Ellis, Peter (2003) The Structure of the Australian Party System and its Strategic Consequences, The Australian Journal of Political Science 38(3):423-443.

The Structure of the Australian Party System

and its Strategic Consequences

David Charnock and Peter Ellis

Faculty of Media, Society and Culture,

Curtin University,

GPO Box U1987,

Perth WA 6845,

Australia.

Corresponding author: David Charnock

Email: D.M.Charnock@curtin.edu.au 
Charnock, David and Ellis, Peter (2003) The Structure of the Australian Party System and its Strategic Consequences, The Australian Journal of Political Science 38(3):423-443.

\section{The Structure of the Australian Party System and its Strategic Consequences}

In this paper we explore the positioning of Australian political parties at the 2001 federal election using data from the Australian Election Study and discuss some of the strategic implications. We focus on some of the attitudes of Senate voters for the various parties, concentrating on how Inglehart's postmaterialism measures and a measure of postmodern attitudes can be used to supplement more traditional left-right descriptions of the party system. We find that descriptions based on a single left-right dimension are inadequate but that attitudes on this dimension and on a postmaterialism or postmodernism dimension are correlated, thus creating constraints for parties. We use comparisons with the 1998 election to assess the stability of the structure and the significance of the electoral context, and generally find that the structure was stable between the two elections. 
Charnock, David and Ellis, Peter (2003) The Structure of the Australian Party System and its Strategic Consequences, The Australian Journal of Political Science 38(3):423-443.

\section{The Structure of the Australian Party System and its Strategic Consequences}

\section{Introduction}

The question of how best to describe and explain changes in the Australian party system has assumed a good deal of significance since the advent of the One Nation Party (ONP) following the election of Pauline Hanson at the 1996 federal election (after she had been disendorsed during the election campaign by the Liberal Party). However, broader questions about the nature of developments in the party system have, of course, been around for much longer than this in the post-WWII period, beginning with the DLP in the 1950s. Later on, and following the decline of the DLP, they again became prominent after the formation of the Australian Democrats in 1977. The development of various regional Green parties (and the subsequent formation of the Australian Greens) has been another significant feature.

Questions about party system change have also, of course, been discussed in broader settings than Australia. There have, for instance, been significant amounts of debate in Europe, where Green and populist anti-migrant parties have achieved a fair deal of electoral success in some countries. One of the most influential accounts of related factors in the international context has been provided by Ronald Inglehart (1977; 1990; 1997), although his argument is not restricted to electoral politics. His earlier account draws on Maslow’s theory of a needs-hierarchy to argue that postmaterialism will play an increasing role; more recently (1997) he has broadened his argument into a consideration of 'postmodernization'.

Inglehart claims that a fundamental shift is taking place in value orientations in modern societies, from an emphasis on traditional priorities maximising economic and physical security to postmodern priorities maximising subjective well-being (Inglehart 1997: 86). He argues that this value shift is reflected in higher interpersonal trust, tolerance and permissiveness and the increasing prioritization of a range of issues such as environmental protection, abortion, ethnic diversity, women's issues, and gay and lesbian emancipation (Inglehart: 1997; 4, 132, 237, 246). The rise of postmaterial values, emphasising self-expression (including political participation) and quality of life issues (such as freedom, democracy, beauty and the importance of ideas), is one 
Charnock, David and Ellis, Peter (2003) The Structure of the Australian Party System and its Strategic Consequences, The Australian Journal of Political Science 38(3):423-443.

component of this changing orientation that he argues has an important impact in the political realm.

In the Australian context, the increase in the vote for the Australian Democrats at the 1990 federal election combined with the apparent significance of environmental issues in that campaign to raise the question of the influence of postmaterialism on voting in Australia to some prominence. Gow (1990: 71), however, concluded that '...economic voting provides a more coherent account of non-Labor voting in the 1990 election.' Part of his argument relied on the extent of first preference votes for the minor parties and, in that context, we can observe that the combined House of Representatives vote for the ALP and the Liberal-National coalition, which had hovered around 90 per cent between 1955 and 1972 (and reached as high as 96 per cent in 1975) had fallen to around 80 per cent in both 1998 and 2001.

In more recent analyses, some aspects of Gow's approach are criticized by Blount (1998), who argues that the postmaterialist effect actually manifests itself in the Senate vote for minor parties. In turn, Western and Tranter (2001) criticize some of Blount's analytical techniques and use multinomial logistic regression to find that postmaterialists vote disproportionately for both the Australian Democrats and the Greens in both the House and the Senate, but that the effects are small.

In the context of ONP, discussions of their support base have drawn on both economic insecurity and attitudes towards race and immigration, although the latter seem to have been more significant than the former at the 1998 election (Charnock 1999; Goot and Watson 2001; McAllister and Bean 2000). Their position at the 1998 election with regard to postmaterialism was, as noted by Western and Tranter (2001), rather unusual inasmuch as ONP voters were also disproportionately postmaterialist.

Analysis in Charnock and Ellis (2001; 2003) also demonstrates this and suggests that the probable explanation lies in measurement flaws with the four-item postmaterialism measure used in the 1998 AES, as argued in another context by Warwick (1998). Charnock and Ellis (2001; 2003) consequently also develop a broader index of postmodern attitudes in line with Inglehart's more recent work and use it and an index of left-right attitudes to explore the structure of the Australian 
Charnock, David and Ellis, Peter (2003) The Structure of the Australian Party System and its Strategic Consequences, The Australian Journal of Political Science 38(3):423-443.

party system. The findings show a structure which is broadly consistent not only with Inglehart's recent work but also that of Kitschelt (1994; 1995) about party competition in Europe.

The most important features of this are that a single left-right dimension is inadequate to describe the structure, but that the practical political impact of the additional dimension is not independent of the left-right dimension. The resulting correlation between attitudes on the two dimensions has strategic consequences for parties, since it constrains their room for independent movement on issue positions related to the two dimensions.

However, it is of course possible that the structure observed in 1998 (or at least some of its important aspects) was particular to that election, especially since that was the first federal election contested by ONP. The highly-charged context in which the 2001 election occurred provides an excellent opportunity to examine the stability of the structure, since the apparently salient issues in relation to terrorism and asylum seekers were very different from the GST-related ones in 1998. Consequently, our initial aim in this paper is to study how closely the structure was replicated at the 2001 election. If the structure is stable, our next aim is to discuss the strategic consequences for the various parties of this structure.

In the course of studying the stability of the structure, we also take the opportunity to address some of the measurement aspects of Inglehart's very widely-used postmaterialism indices. This is possible because the 2001 Australian Election Study incorporated the full 12-item battery rather than just the 4-item version which showed the anomalous results for ONP when it was asked in the 1998 AES.

\section{Data and measures}

Our analyses are based on data from the 2001 Australian Election Study (Bean et al. 2002) $)^{1}$ and we follow Blount (1998) and Charnock and Ellis (2001; 2003) in studying Senate vote. This is partly because the multi-member, quota-preferential voting system in the Senate is more 'minor party-friendly' because of its more proportional outcomes than the House of Representatives (which makes it more likely that changes to the structure of the party system will be apparent there first), and also because there 
Charnock, David and Ellis, Peter (2003) The Structure of the Australian Party System and its Strategic Consequences, The Australian Journal of Political Science 38(3):423-443.

is greater consistency in choice offered to voters in the Senate ${ }^{2}$. In the House, voters in each electoral division not only possibly face constituency-specific issues and personalities, but also not all parties offer candidates in every contest.

\section{Left-Right economic ideology}

With the questions available in the 2001 AES and in keeping with the measure used in Charnock and Ellis (2001; 2003), we formed an index ${ }^{3}$ based both on individual selfplacement on a left-right scale and also on responses to some relevant individual questions, specifically:

\section{AES variable}

D14P4

D14P2

D14P5

E1

B10OWN
Question summary

Income and wealth should be redistributed

Trade unions have too much power

Stricter laws to regulate trade unions

Choice between taxes and social services

Own left-right position

\section{Left position}

Strongly agree

Strongly disagree

Strongly disagree

Strongly favour social services

Extreme left

At the core of this index is the notion that the left-right division reflects conflicting economic interests centring around the ownership of the means of production and distribution of income. The index was scaled to have a range of values from 0 to 1 , with 0 indicating extreme left-wing and 1 indicating extreme right-wing.

\section{Postmaterialism}

Increasing demands for political expression and participation are seen as key indicators of Inglehart's concept of postmaterial values emphasising self-expression. He contrasts these values with those prioritising more materialist concerns with the nation's economic management and physical security. Although the measurement and interpretation of postmaterialism are topics of some controversy in the political science and other literature (for example, see Clarke et al 1999; Davis and Davenport 1999; Inglehart and Abramson 1999), there are two standard measures of postmaterialism (see the appendix for details). The first (which was the earliest one used) is based on a single ranking exercise, with four national aims (two materialist 
Charnock, David and Ellis, Peter (2003) The Structure of the Australian Party System and its Strategic Consequences, The Australian Journal of Political Science 38(3):423-443.

and two postmaterialist) from which to select. The second is based on three such questions, making a total battery of twelve items.

The four-item battery results in classifications of survey respondents as 'materialist', 'postmaterialist', or 'mixed'. The standard way of aggregating this figure by group (party, country, etc) is to cite the difference between the percentage of postmaterialists and the percentage of materialists (e.g. Inglehart 1997: 136). As outlined in the appendix, the twelve-item battery results in a score ranging from zero (completely materialist) to five (completely postmaterialist) (Inglehart 1997: 130). Inglehart (for example, see Inglehart 1997: 145, 151) seems to prefer to aggregate this in a similar manner to the one used for the four-item battery and cites the difference between the percentages of 'high' postmaterialists (scores of three or more) and 'low' postmaterialists (score of zero); we have chosen to cite mean scores instead (though we found in our analyses that the two approaches actually resulted in very similar interpretations).

The choice of rival aims offered in the four-item battery (used in the 1998 AES) is as follows (with the first and third aims regarded as materialist):

- maintaining order in the nation;

- giving people more say in important government decisions;

- fighting rising prices;

- protecting freedom of speech.

Warwick (1998) argues that the four-item measure is actually revealing a 'prodemocracy' orientation. The finding (Charnock and Ellis 2001, 2003) that ONP voters in 1998 were disproportionately postmaterialist by this measure seems to bear this out. In the Australian context at the time, ONP voters were often characterised as anti-elite, feeling left out of the Australian political and economic landscape, and opponents of 'political correctness' as a form of implicit censorship of 'ordinary Australians', and it is perhaps unsurprising that many were inclined to believe that the second and fourth of the aims were important ones for Australia. The different electoral context in 2001, however, might well lead to different choices for the most 
Charnock, David and Ellis, Peter (2003) The Structure of the Australian Party System and its Strategic Consequences, The Australian Journal of Political Science 38(3):423-443.

important aims. If so, the dependence of the four-item measure on context would provide another argument against its validity. One would expect, however, that the 12-item measure would be more robust.

\section{Postmodernism}

While Inglehart (1997) argues that the postmodern dimension of politics he identifies is strongly associated with the postmaterialism-materialism divide, he does also recognise that a broader consideration of postmodern politics will sometimes be necessary. Because of the above-mentioned anomalous results provided for ONP in 1998 by the four-item postmaterialism measure, Charnock and Ellis (2001; 2003) use this broader approach to study the party system structure at the 1998 election. As many readers will be aware, terms relating to postmodernism often have different and competing meanings (cf Gibbins and Reimer 1999) and, unlike in the case of postmaterialism, Inglehart does not have a standard operationalisation of postmodernism. Consequently, the most natural approach to develop ours is by basing it directly on key aspects involved in his suggested new dimension.

Inglehart argues that a key implication of the re-orientation toward postmodern values is a shift in political cleavages based on class conflict toward cleavages based on cultural issues and quality of life concerns (1997: 237). Postmodernization is associated with increasing levels of interpersonal trust, tolerance and permissiveness and a de-emphasis on all kinds of authority, whether religious or secular, in favour of individual pursuit of subjective well-being (1997: 74). As previously noted, postmodern values have been associated with the increasing prioritization of a range of issues, such as environmental protection, abortion, ethnic diversity, women's issues, and gay and lesbian emancipation (Inglehart: 1997; 4, 132, 237, 246). Accordingly, drawing on the data available in AES2001 and giving specific attention to the importance of Aboriginal issues in the Australian context, we followed the approach adopted in Charnock and Ellis (2001; 2003) and created 5 indices (see below) to measure individuals' positions on permissiveness, xenophobia, rights for minority or oppressed groups and environmental priorities. As with the left-right economic ideology index, each index was scaled to range from 0 to 1 , with 1 indicating the most postmodern stance. 
Permissiveness (PERMIS)

AES variable

E2NUDSEX

E3

E4DEATHP

E4LAWBRK

E4MARIJ

E10P5

\section{Question summary}

Nudity \& sex in films and magazines

Feelings about abortion

Death penalty should be reintroduced for murder

Stiffer sentences if break law

Decriminalise smoking of marijuana

Importance of traditional ideas of right and wrong

\section{Attitudes to immigrants (IMMIG)}

E2MIGEO Equal opportunities for migrants

F6

F7P1

F7P3
Number of immigrants increased

Immigrants increase crime

Immigrants take jobs from Australian born

\section{Environmentalism (ENV)}

$\begin{array}{ll}\text { E5P1 } & \text { Env concern - pollution } \\ \text { E5P2 } & \text { Env concern - waste disposal } \\ \text { E5P3 } & \text { Env concern - logging of forests } \\ \text { E5P4 } & \text { Env concern - destruction of wildlife } \\ \text { E5P5 } & \text { Env concern - soil degradation }\end{array}$

E6

How likely to join env group

Very urgent

Very urgent

Very urgent

Very urgent

Very urgent

Already a member

Attitudes towards Aborigines (AB)

E2ABLAND Aboriginal land rights

E2ABOR Government help for Aborigines

G10P6

G10P9
Recognise aspirations of Aborigines

Aborigines' right to self-government
Not gone nearly far enough

Not gone nearly far enough

Strongly agree

Strongly agree 
Charnock, David and Ellis, Peter (2003) The Structure of the Australian Party System and its Strategic Consequences, The Australian Journal of Political Science 38(3):423-443.

\section{Attitudes towards equal opportunities (EEO)}

E2EQUOP Equal opportunities for women

E4OPP

E10P2

E10P3

E10P4
Increase business opportunities for women Importance of EEO in hiring and promotion

Importance of special effort to protect minorities

Importance of equality between men and women
Not gone nearly far enough

Strongly agree

Very important

Very important

Very important

An implication of Inglehart's ideas is that attitudes towards these kind of issues actually flow from a fairly coherent underlying value orientation and so, if Inglehart's thesis is correct, these attitudes should to a reasonable degree be able to be summarised in a single dimension ${ }^{4}$. Accordingly, in addition to looking at the five indices separately, we can also calculate a single 'postmodern attitudes' index, based on all 25 questions. It then becomes an empirical question as to whether using the five separate indices adds anything of significance to our understanding of voting behaviour, when compared to using the single combined postmodern attitudes index.

Given the context of the 2001 election, we also investigated the significance of attitudes to defence/security issues and cultural pluralism. The corresponding indices are as follows ${ }^{5}$ :

\section{Defence (DEF)}

E2TERROR Australian support for fight against terrorism

E4MILITR Australia have compulsory military service

F4 Government spend more on defence

F5P5 Australia provide military for war on terrorism

\section{Pluralism (PLUR)}

E4ASYLUM Asylum seekers should be turned back

G10P2 Distrust people who try to be different

G10P5 People come here should be more like Australians

G10P8 Important new migrants learn to be Australian 
Charnock, David and Ellis, Peter (2003) The Structure of the Australian Party System and its Strategic Consequences, The Australian Journal of Political Science 38(3):423-443.

The inclusion of E4ASYLUM in the Pluralism index (rather than in the Defence one) is perhaps surprising, but is justified by factor analyses that show this is where it is better-placed. It seems that, in this context, asylum seekers are seen as 'queue jumpers' and as breaking a norm of Australian culture, rather than as a security threat along the same lines as terrorism.

Our data analyses proceed as follows. We begin by examining the location of parties' voters at the 2001 election in the two-dimensional spaces formed by linking left-right attitudes to each of the two postmaterialism measures and the combined postmodern attitudes index. Following this, we use multinomial logistic regression to estimate various models relating vote in 2001 to the various attitudinal indices. Finally, we study the attitudinal consistency of the voters for the various parties.

\section{Results and Discussion}

Before moving to consider the impact on voting, we briefly consider the overall association between the left-right index and the postmaterialism and the combined postmodern attitudes indices. In line with the argument outlined earlier, these show fairly strong negative relationships, with a correlation coefficient of -0.42 between the left-right index and the postmodern attitudes index, and one of -0.40 between the leftright index and the 12-item postmaterialism measure. In other words, those who have more postmodern attitudes or are more postmaterialist also have a tendency to be more left-wing.

It is not surprising that this association between attitudes at the level of individual voters is also reflected in the average positioning of voters for the various parties. Figure 1 shows the relationship for each party's Senate voters between their mean score on the left-right index and the relative balance of postmaterialists and materialists (based on the four-item measure). Figure 2 is similar, but with the fouritem postmaterialism measure replaced by the mean postmaterialism score based on the twelve-item measure. An examination of these Figures reveals that in 2001 both showed essentially the same features, with the overall pattern of the relationship between left-right attitudes and postmaterialism being similar to the diagonal structure 
Charnock, David and Ellis, Peter (2003) The Structure of the Australian Party System and its Strategic Consequences, The Australian Journal of Political Science 38(3):423-443.

in comparable two-dimensional attitudinal space found in Europe by Kitschelt (1995) and mentioned earlier.

\section{FIGURE 1 ABOUT HERE}

\section{FIGURE 2 ABOUT HERE}

This positioning of parties' voters is quite significant. First, it supports Inglehart's more recent argument (following Kitschelt) that the practical impact of the 'new politics' dimension is not orthogonal to the more traditional left-right dimension (see, for example, Inglehart 1997: 246).

Second, it suggests that it might be useful to regard party competition as now taking place along a new axis, but one which is located within a two-dimensional space (as opposed to descriptions locating competition along a single, left-right dimension). It is clear, for instance, that describing ONP as a 'far right' party (as is very commonly done) is a quite inadequate way of understanding their support and can only serve to mislead. Their supporters were, in fact, more centrist on average in terms of left-right attitudes in 2001 than were those of either the Liberal or National parties (and this was also the case in 1998 (Charnock and Ellis 2001, 2003)). By both measures they were also somewhat less materialist than coalition voters.

On these two dimensions there was essentially no difference between Liberal and National Senate voters in 2001. Democrats voters occupy a slightly left of centre position on economic issues but are somewhat more postmaterialist than the ALP. Greens voters are both the most postmaterialist and also the most left-wing party, and the Greens are better described as a left-libertarian party than by Inglehart's depiction of postmaterialists who have little interest in classic left redistributive agendas (Inglehart 1997: 246). 
Charnock, David and Ellis, Peter (2003) The Structure of the Australian Party System and its Strategic Consequences, The Australian Journal of Political Science 38(3):423-443.

As noted earlier, an important consequence of the correlation between attitudes on the two dimensions is that it reduces the capacity of parties to treat them independently. A quite recent example is the negative reaction from members of the Greens party that followed after Greens’ Senator Bob Brown made the suggestion that further privatization of Telstra might be acceptable provided some of the proceeds were used for appropriate environmental uses.

As far as the stability over time of the structure is concerned, the four-item measure demonstrates many similarities with 1998 (see Charnock and Ellis 2003, Figure 2), but also a number of significant differences. As mentioned earlier, perhaps the main difference is that, unlike in 2001, the measure quite counterintuitively showed ONP voters as being disproportionately postmaterialist in 1998, but another noticeable aspect was that the measure also showed almost as many postmaterialists as materialists among Liberal and National voters in 1998, in contrast to 2001.

Both of these facts reinforce the argument that the four-item measure does not always measure what it is intended to. Since the twelve-item battery was not asked in the 1998 AES, however, there is no point of comparison for the more extensive measure of postmaterialism. Therefore, in order to obtain some evidence about the stability of the structure of party competition between 1998 and 2001 based on something more reliable than the four-item postmaterialism measure, we show in Figure 3 the results of regarding the second relevant dimension as a postmodern attitudes one, along the lines of Inglehart's more recent work.

\section{FIGURE 3 ABOUT HERE}

This Figure does, in fact, reveal a structure that is similar both to that revealed in Figure 2 by the 12-item postmaterialism measure and also to a comparable analysis of a postmodern attitudes index for the 1998 election (Charnock and Ellis 2003). It seems, therefore, that the structure of party competition at the two elections was quite stable, and later in this article we examine some of the implications of this structure. Here, we simply note the very important feature that differences between ALP and coalition voters are mainly defined by the left-right dimension, although there are also 
Charnock, David and Ellis, Peter (2003) The Structure of the Australian Party System and its Strategic Consequences, The Australian Journal of Political Science 38(3):423-443.

some smaller differences between them in terms of the postmaterialism/postmodern attitudes dimension.

\section{Individual voting models}

Up to this point, we have used graphical representations of party competition. We now extend our analyses by estimating models that relate individual voting to the various indices. We include the same models as in Charnock and Ellis (2003), and also add some others that use the 12-item postmaterialism measure.

In addition to a null model (to obtain a baseline for assessing the other models), we present complete details of six models: one with only the left-right economic index (model A1), one with only the single 12-item postmaterialism measure (model A2), one with only the postmodern attitudes index (model A3), a model with both the leftright index and the 12-item postmaterialism measure (model B1), a model with both the left-right index and the postmodern attitudes index (model B2), and one with the left-right economic index and all five of our separate indices for the different components of postmodern attitudes (model C). Examination of these models allows us to assess not only the relative importance of left-right, postmaterialism and postmodern attitudes, but also whether studies using the five separate indices add much over ones using only the single postmodern index.

We use multinomial logistic modelling (see, for example, Long 1997). In this form of modelling, one category of the dependent variable is set as a reference category. As above, we study Senate vote, and we make Liberal vote the reference category. We can then meaningfully separate Liberal from National voters, and thus examine differences between the two coalition partners, something that is not often done in Australian voting analyses.

\section{TABLES 1 TO 7 ABOUT HERE}

Tables 1 to 7 show the results of our main models (null and models A1, A2, A3, B1, B2 and C as outlined above). Unbracketed numbers are the estimates of the size of the logit coefficient compared to Liberal voters; bracketed numbers are the corresponding standard errors. Hence, a coefficient that is statistically significantly different from 
Charnock, David and Ellis, Peter (2003) The Structure of the Australian Party System and its Strategic Consequences, The Australian Journal of Political Science 38(3):423-443.

zero indicates significant evidence of a difference from the Liberals on the corresponding attitudinal index.

A negative coefficient for the 'left-right economic' variable indicates Left-wing voters are more likely to vote for that party than for the Liberals; a negative coefficient for the various postmaterialism and postmodern indices indicates postmaterialist or postmodern voters, respectively, are less likely to vote for that party than for the Liberals. Coefficients should be interpreted as showing the association between the variable and vote once the other variables in that particular model have been controlled for. Thus, looking at the bottom row of Table 6 (Model B2), we see that, having controlled for left-right economic position (for which being more left-wing increases the odds of voting for ONP rather than the Liberals), having postmodern attitudes decreases the odds of voting ONP compared to the Liberals.

The initial models (A1, A2 and A3) essentially confirm the picture of party support differentiation previously obtained from Figures 1,2 and 3, but they also demonstrate (by comparison of the measures of model fit with those from the null model) that the association between voting and the left-right economic index is overall of more significance than is that with the postmaterialism or postmodern indices (though these, also, are certainly of importance).

For example, including only the left-right index (model A1) reduces AIC ${ }^{6}$ by 545, whereas including only the postmaterialism 12-item measure (model A2) reduces AIC by just over half as much (331) and including only the postmodern attitudes index (model A3) reduces AIC by 404. However, both dimensions are important: including both reduces AIC by a total of 682 (model B1) or 775 (model B2) from the null model. In 1998, in contrast, a model that included only postmaterialism (based on the 4-item battery) as an explanatory variable resulted in a very small reduction in AIC over the null model of only 14. On the other hand, the postmodern attitudes index gave a large reduction in AIC in 1998 also, although somewhat less than in 2001 (Charnock and Ellis 2003). The coefficient estimates also clearly show that the leftright economic dimension continues to be primary for differentiating the ALP and Liberal parties from each other. 
Charnock, David and Ellis, Peter (2003) The Structure of the Australian Party System and its Strategic Consequences, The Australian Journal of Political Science 38(3):423-443.

Separating the postmodern index into its five sub-indices (model C) does enhance the model compared to model B2, although the extra improvement in model fit is overall relatively small. There is an extra reduction in AIC of 72 compared to the single postmodern attitudes index, indicating that the addition of the single, combined postmodern index captures most of the improvement by itself. Nevertheless, there are other detailed differences between some of the parties that are apparent when the five sub-indices are included and some of these are of interest because they enable a finergrained picture to be obtained ${ }^{7}$. For example,

- Although there was a general tendency for being more postmodern to increase the chances of voting ALP compared to Liberal, the opposite was the case for attitudes towards immigrants when the other attitudes are controlled for. This was also true at the 1998 election, thus reinforcing for the ALP the dilemma (observed in Charnock 1997) that results from the fact that Asian migrants in particular give them disproportionate support.

- In 2001, being more postmodern had an overall tendency to increase the chances of voting Australian Democrats rather than Liberal, and the same was also true in 2001 at the level of each of the sub-indices separately. Compared to the ALP, being economically more right-wing and more supportive of environmental issues, more culturally permissive and more favourably inclined towards immigrants also significantly increase the chances of voting Democrat.

- Once the other attitudes are controlled for, the impact on voting of attitudes towards immigrants and EEO does not differentiate between Green and Liberal voters. On the surface this may seem surprising, but appears to be a stable feature since it was also true in 1998. The strand in Green thought that links environmental pressure with population growth and immigration may be important here.

- Compared to voting Liberal or National, being more economically left-wing significantly increases the chances of voting for the One Nation Party, but has 
Charnock, David and Ellis, Peter (2003) The Structure of the Australian Party System and its Strategic Consequences, The Australian Journal of Political Science 38(3):423-443.

the opposite effect on the chances of voting for ONP compared to voting for the ALP.

In descending order of size, having postmodern attitudes towards immigrants and aboriginal issues significantly decrease the chances of voting for ONP compared to Liberal. The same is also the case for voting ONP compared with voting ALP, In addition to the left-right difference noted above, the main differentiating factors in voting ONP rather than National are significantly more negative attitudes towards immigrants and aborigines.

Whether focusing on the separate sub-indices or on the combined index, a major conclusion from these models is that either a postmaterialism or postmodern political dimension is of importance in helping understand Senate vote. Interestingly, the position of ONP voters in 2001 is still shown as being more postmaterialist than that of coalition voters, though the difference is much smaller than in 1998. The broader measure of postmodern attitudes, however, shows ONP voters as having the least postmodern attitudes.

Which of the two conceptualizations of the second dimension is more useful could be a matter of debate. Statistically, however, the postmodern attitudes index improves model fit more than does either of the two postmaterialism measures. Decomposing the postmodern political dimension into five sub-components allows an even finer characterization of differences between parties.

\section{FIGURE 4 ABOUT HERE}

The attitudinal positions of voters for different parties on the various individual indices (including defence and pluralism) can also be depicted separately in graphical form, as in Figure 4. Despite their apparent contextual importance at the 2001 election, it is clear from this diagram that the defence and cultural pluralism indices add little to the picture of party competition obtained from the other attitudinal subindices. The ordering of party voters (other than on the left-right index) is, in almost all cases, Green; Democrat; ALP; Liberal/National; ONP. 
Charnock, David and Ellis, Peter (2003) The Structure of the Australian Party System and its Strategic Consequences, The Australian Journal of Political Science 38(3):423-443.

\section{Attitudinal consistency, Distances between parties and Strategic implications}

From a strategic point of view, although the picture we have been able to draw up to this point is certainly very useful for differentiating between the parties, it is essentially based on average attitudinal positions. Another interesting and practically important issue is to examine how much attitudinal variation is present among the voters for each party, and how large are the average distances between the parties' voters. To the extent that the attitudes being studied here are ones that have an impact on voting behaviour, we can use this information as a guide to how much scope there is for parties to attract voters from (or lose voters to) other parties. It also gives a rather more precise indication of what we might describe as parties with the most 'closely ideologically aligned’ supporters.

Since our multinomial logistic modelling has shown that using the five separate postmodern sub-indices (model C) improves model fit by a relatively small amount compared to the model (B2) with the left-right economic attitudes index and the combined postmodern attitudes indices, we reduce complexity by restricting ourselves to examining the two-dimensional space formed by the left-right and postmodern attitudes' indices. This also has the advantage of allowing us to make visual comparisons.

The inner and outer contour lines in Figure 5 enclose $40 \%$ and $80 \%$ respectively of the estimated population voting for each party ${ }^{8}$. We have inserted the axes around a central point $(0.5,0.5)$ in order to more readily make visual distinctions between leftand right-wing voters, and between more or less postmodern voters.

\section{FIGURE 5 ABOUT HERE}

It is immediately obvious that there is a considerable degree of crossover between the supporters of the various parties, despite the degree of separation between the centres of density for each party previously indicated in Figure 3 (and Figures 1 and 2 when using the two postmaterialism measures). This is, of course, important because it gives rise to potential vote switching between parties.

As in 1998, the general pattern is for the core of voters for all parties to have quite coherent attitudes, but for this to be less so for remaining voters (much less so for 
Charnock, David and Ellis, Peter (2003) The Structure of the Australian Party System and its Strategic Consequences, The Australian Journal of Political Science 38(3):423-443.

Democrats and Greens voters especially). Considering the two-dimensional space overall, the most internally consistent attitudes were held by voters for the two coalition parties, closely followed by ONP and the ALP, while voters for the Greens and Democrats clearly did not have attitudes that were as consistent as those of other parties. Refining this by examining the two dimensions separately, the conclusions are only slightly different. The Greens are differentiated from the Democrats by being the least consistent on both dimensions, whereas Democrats' voters are about as consistent as ONP and ALP voters on the left-right dimension. As was the case overall, coalition voters were the most consistent on each of the dimensions considered separately.

One interesting finding here is that the attitudes of ONP voters were overall more consistent than the Greens and Democrats and were, in fact, a little more consistent than those of ALP voters. Again, to the extent that these attitudes are significant in determining voting behaviour, the position of the ALP seems slightly weaker than the Liberals, though the extent of the intra-party variations for most of the parties is fairly large. Although not shown here, a more detailed numerical analysis of intra-and interparty average distances confirmed that, as was also the case in 1998 (Charnock and Ellis 2003), voters for the more right-wing parties (Liberals, Nationals and ONP) were more ideologically coherent in 2001 than those voting for the other parties (ALP, Democrats, Greens).

\section{Conclusion}

Most of the conclusions we draw from our analyses apply to both of the 1998 and 2001 elections, although a few are particular to 2001. In the case of the former, for example, our analyses clearly demonstrate that in both 1998 and 2001 a single, leftright economic dimension was insufficient to adequately describe voter differences between Australian parties, although it does remain the main aspect dividing ALP from Liberal Party voters.

Whether we choose to conceptualise the second required dimension in terms of postmaterialist attitudes or the somewhat broader postmodern attitudes is not a matter of enormous empirical consequence in 2001 since both result in fairly similar descriptions of the patterns of party competition, with just a few differences 
Charnock, David and Ellis, Peter (2003) The Structure of the Australian Party System and its Strategic Consequences, The Australian Journal of Political Science 38(3):423-443.

(especially in relation to ONP). This is unlike the situation in 1998, when the 4-item postmaterialism measure incongruously showed ONP voters to be disproportionately quite postmaterialist, suggesting to us (as to several other writers) that it is too contextually bound ${ }^{9}$ to be a reliable measure of postmaterialism. The 12-item postmaterialism measure was not asked in the 1998 AES, so we cannot draw any conclusion from this analysis about its reliability; on the surface, however, it would seem unlikely that it would be as unreliable in measuring postmaterialism as the simpler 4-item measure.

In both 1998 and 2001, it was the left-right dimension that was of more overall importance as far as measures of model fit are concerned; this is largely a consequence of the above-noted fact that it is this dimension that primarily serves to differentiate between the two largest blocs of voters, those for the ALP and the Liberal Party. However, rather than considering the two dimensions separately, it might be more advantageous to consider the structure from another perspective, with our findings at both elections indicating the existence of a new axis of party competition. This axis, though, appears as a diagonal line in the two-dimensional attitudinal space, much as in Kitschelt's description of the structure of European party competition and not dissimilarly to Inglehart's more recent arguments.

Breaking the postmodern attitudes index down into its subcomponents gives an even more detailed picture of differentiation of voter support, particularly between the minor parties, although for the reason mentioned above it does not add a great deal in terms of improvement in measures of overall model fit.

Although the two elections occurred in very different contexts (one very much focused on the proposed GST and the other apparently strongly influenced by considerations of international terrorism and the issue of asylum seekers in the context of the MV Tampa incident), our analyses show that the structure of party competition was very similar at both Senate elections. The correlation between attitudes on the two dimensions that is indicated by this structure places constraints on the ability of parties to adopt issue positions relevant to the two dimensions independently of each other. These constraints will undoubtedly continue to prove awkward to deal with at times, most obviously for the major parties. 
Charnock, David and Ellis, Peter (2003) The Structure of the Australian Party System and its Strategic Consequences, The Australian Journal of Political Science 38(3):423-443.

To us, this suggests that the strategic nature of the Australian party system has now developed to a point where the competition offers far more complex possibilities. Although the vote for ONP dropped between 1998 and 2001 (from 9.0 per cent to 5.5 per cent in the Senate and from 8.4 per cent to 4.3 per cent in the House of Representatives), it is nevertheless plausible that there is a medium-term place for it (or another similar party) in the party system provided, of course, that it (or a similar party) can achieve a degree of organizational stability.

There are significant amounts of intra-party variation in attitudes. As a result, there are quite large degrees of overlap between the voters for the various parties, again opening up the possibility of vote-switching between parties. In this regard, we found in both 1998 and 2001 that the greatest degree of internal coherence was to be found among the three more right-wing parties (Liberal, National, ONP), which would seem to be a factor tending to give them a firmer support base.

In thinking about the impact of the structure of the system it is, of course, important to remember that changes in issue positioning by one party have an effect on others and that the behaviour of all parties influences what is feasible for the others.

Nevertheless, at both elections, we found a rough clustering of voters into two camps: one (Greens, Australian Democrats, ALP) more left-wing and more postmodern and the other (Liberal, National, ONP) more right-wing and less postmodern. This finding gives added significance to the question of whether or not the coalition parties should direct high-order preferences towards ONP (or a similar party). This clearly requires very careful consideration on the part of the Liberals and Nationals and also might be seen to have a bearing on another related issue, that of whether the Liberals and Nationals should formally amalgamate. It would, though, seem to be a rather risky strategy to end up with a single party to replace what is currently a three-party cluster.

In tactical terms, the parallels between the two camps are not complete. The ALP is not the most left-wing of its 'cluster', whereas both the Liberals and Nationals are more right-wing than ONP. This places ONP (with the more centrist average economic views of its supporters) in a different position from the Greens, for example, since ONP has the potential to act as a 'bridge' between the ALP and the coalition parties. It also means, of course, that ALP support can be subject to attrition 
Charnock, David and Ellis, Peter (2003) The Structure of the Australian Party System and its Strategic Consequences, The Australian Journal of Political Science 38(3):423-443.

from two directions, with the Greens attracting some of their more left-wing and postmodern voters if the ALP adopts policy positions to shore up its support among more right-wing and less postmodern voters. Preferential voting methods might be helpful in recovering some of these losses at later stages of vote counting, but indefinitely relying on this seems to be inherently risky. In the medium- to long-term, it would presumably be better to aim to both move public opinion to positions more congenial to the ALP and also to attempt to adopt strategies to fragment the voting support of the more right-wing parties.

Our analysis is also relevant to debates over the positioning of the Australian Democrats, since the location of the main density of voters in the two-dimensional attitudinal space does not seem conducive to the long-term presence of two parties to the left of the ALP. The fact that Democrats' voters were more consistent than Greens' voters on the left-right dimension is another relevant consideration here. However, regardless of the debates about where particular parties should position themselves, one thing that is clear is that the strategic complexity of the Australian party system has increased and that future federal politicians seem certain to be condemned to 'live in interesting times.' 
Charnock, David and Ellis, Peter (2003) The Structure of the Australian Party System and its Strategic Consequences, The Australian Journal of Political Science 38(3):423-443.

David Charnock is an Associate Professor in the Faculty of Media, Society and Culture at Curtin University. He researches and teaches in the areas of Australian politics and social demography. Peter Ellis has qualifications in development studies and applied statistics and is now Director of the Program Evaluation Section in AusAID. This article is not connected in any way to the views of AusAID.

We thank Kay Fisher and the journal's reviewers for their comments on earlier drafts. This research was partially supported by Australian Research Council Large Grant number A79938063.

\section{Notes}

1. The 2001 Australian Election Study had a completed sample size of 2010 respondents. The data are available from the Social Sciences Data Archives (http://ssda.anu.edu.au) at the Australian National University (SSDA Study Number 1048).

2. We did repeat some analyses for voting in the House of Representatives, and these did actually show a similar overall structure to the ones for Senate vote presented here, though there are some differences of detail.

3. One of the items included in the index used in Charnock and Ellis (2001; 2003) (D13SOCEC, asking whether Australia would be better off with a socialist economy) was not asked in the 2001 AES and hence had to be omitted here. When respondents did not reply to all of the items in the indices, we used imputation of missing data, with very similar results being obtained from different imputation methods. All of our indices (other than the two longestablished, standard postmaterialism measures) are constructed by taking the mean of the item scores (each standardized to a 0 to 1 range).

4. Evidence in support of this is provided by the facts that almost all of the 25 items have significant loadings on the first principal component, and that this component by itself explains 24 per cent of the total variance. 
Charnock, David and Ellis, Peter (2003) The Structure of the Australian Party System and its Strategic Consequences, The Australian Journal of Political Science 38(3):423-443.

5. Reliability coefficients for the various indices were as follows: Left-Right Economic (0.65); Combined Postmodern (0.84); PERMIS (0.57); IMMIG (0.81); ENV (0.85); AB (0.81); EEO (0.70), DEF (0.64), PLUR (0.74).

6. AIC, 'Akaike's Information Criterion' is an indicator of goodness of fit that is widely used to compare rival models if they differ only in the choice of explanatory variables. AIC consists of the model deviance penalised by adding twice the number of parameters in the model.

7. Also see the appendix for an odds ratio-based presentation of the model C results.

8. The contour plots are based on bivariate normal kernel density estimates smoothed using locally weighted regression. For the former, see the S-Plus function kde2d described in Venables and Ripley (1999: 446).

9. An alternative explanation for the disproportionately postmaterialist ONP support in 1998 might be that ONP attracted supporters from other parties who were postmaterialist and who subsequently returned to voting for other parties in 2001. The sample sizes involved are far too small for the AES to give any reliable direct evidence about this, but the fact that ONP supporters are shown as being the least postmodern in both 1998 and 2001 provides a strong argument against this alternative suggestion. 
Charnock, David and Ellis, Peter (2003) The Structure of the Australian Party System and its Strategic Consequences, The Australian Journal of Political Science 38(3):423-443.

\section{Appendix}

\section{Postmaterialism indices}

One of Inglehart's two materialism-postmaterialism indices (used in the earliest research) is based on a four-item battery; the other index is based on a twelve-item battery, which consists of 3 separate ranking exercises, the second of which is effectively the four-item battery (Inglehart 1997: 355). Each of the ranking exercises is prefaced with the question "There is a lot of talk these days about what the aims of this country should be for the next ten years. On this card are listed some of the goals which different people would give top priority. Would you please say which one of these you, yourself, consider the most important? And which would be the next most important?”

The options for the first question are: "maintaining a high level of economic growth; making sure that this country has strong defence forces; seeing that people have more to say about how things are done at their jobs and in their communities; trying to make our cities and countryside more beautiful”.

The options for the second question (which is effectively the four-item battery) are: "maintaining order in the nation; giving people more say in important government decisions; fighting rising prices; protecting freedom of speech”.

The options in the third question are: "having a stable economy; progress towards a less impersonal and more humane society; the fight against crime; progress towards a society in which ideas count more than money”.

From the twelve-item battery, a postmaterialism index is created from the number of the six options chosen which are postmaterialist rather than materialist - the distinction should be fairly obvious to the reader, except in the case of "trying to make our cities and countryside more beautiful”, which Inglehart does not include on the side of postmaterialism because of low correlation with the other postmaterialist options, apparently tapping instead into fears about urban crime. Consequently, Inglehart does not include this item in his postmaterialist index, which thus ranges from zero (completely materialist) to five (chose all the available postmaterialist options). 
Charnock, David and Ellis, Peter (2003) The Structure of the Australian Party System and its Strategic Consequences, The Australian Journal of Political Science 38(3):423-443.

In the 2001 AES, the four-item battery was asked as the first of the three sets of four responses, as compared to the second set (as outlined above). We assume that this should make comparisons of the four-item measure between the 1998 AES (when it was the only set asked) and the 2001 AES more reliable than if Inglehart's ordering had been used.

\section{Odds ratio changes presentation of Model C}

An alternative presentation of the results of multinomial logistic regression models is based on odds ratios. Since this involves comparisons of all pairs of parties, it generates large sets of numbers and so we only give such a presentation for our most complex model (C).

\begin{tabular}{lrrrrrr}
\hline & Left-right & PERMIS & IMMIG & ENV & AB & EEO \\
\hline Lib/ALP & 2.24 & 0.99 & 1.16 & 1.04 & 0.85 & 0.87 \\
Lib/Nat & 1.02 & 1.12 & 1.07 & 1.10 & 0.97 & 0.97 \\
Lib/Dem & 1.64 & 0.83 & 0.87 & 0.83 & 0.80 & 0.88 \\
Lib/Grn & 1.93 & 0.75 & 1.01 & 0.60 & 0.71 & 0.96 \\
Lib/ONP & 1.58 & 0.94 & 1.37 & 0.94 & 1.19 & 1.05 \\
ALP/Nat & 0.46 & 1.13 & 0.92 & 1.06 & 1.14 & 1.12 \\
ALP/Dem & 0.73 & 0.83 & 0.74 & 0.80 & 0.94 & 1.02 \\
ALP/Grn & 0.86 & 0.76 & 0.87 & 0.58 & 0.84 & 1.10 \\
ALP/ONP & 0.70 & 0.94 & 1.18 & 0.90 & 1.40 & 1.20 \\
Nat/Dem & 1.60 & 0.74 & 0.81 & 0.75 & 0.82 & 0.91 \\
Nat/Grn & 1.89 & 0.67 & 0.95 & 0.55 & 0.73 & 0.99 \\
Nat/ONP & 1.54 & 0.84 & 1.28 & 0.85 & 1.22 & 1.08 \\
Dem/Grn & 1.18 & 0.91 & 1.17 & 0.73 & 0.90 & 1.08 \\
Dem/ONP & 0.96 & 1.13 & 1.58 & 1.13 & 1.50 & 1.18 \\
Grn/ONP & 0.82 & 1.25 & 1.35 & 1.56 & 1.67 & 1.09 \\
\hline
\end{tabular}

The table shows, for each pair of parties, the proportional change in the voting odds for an increase of 0.1 in the indicated index. Two examples illustrate how the table can be interpreted: first, moving 0.1 along the economic index to the right will increase the odds of voting Liberal rather than Labor by about two and one quarter- 
Charnock, David and Ellis, Peter (2003) The Structure of the Australian Party System and its Strategic Consequences, The Australian Journal of Political Science 38(3):423-443.

fold (2.24 times) over what they would have been otherwise; second, moving 0.1 in the postmodern direction of the permissiveness index will reduce the odds of voting Liberal rather than Green to three-quarters ( 0.75 times) what they would have been otherwise. 
Charnock, David and Ellis, Peter (2003) The Structure of the Australian Party System and its Strategic Consequences, The Australian Journal of Political Science 38(3):423-443.

\section{References}

Bean, C., D. Gow and I. McAllister. 2002. Australian Election Study 2001: User's Guide for the machine-readable data file. Canberra: Social Science Data Archives, Australian National University.

Blount, S. 1998. 'Postmaterialism and the Vote for the Senate in Australia.' Australian Journal of Political Science 33(3): 441-449.

Charnock, D. 1999. 'Voting at the 1998 Australian Federal Election: Studying major and minor parties simultaneously.' In Proceedings of the 1999 Conference of the Australasian Political Studies Association. Sydney: Department of Government, University of Sydney / APSA, vol. 1: 91-99.

Charnock, D. 1997. 'Spatial Variations, Contextual and Social Structural Influences on Voting for the ALP at the 1996 Federal Election: Conclusions from Multilevel Analyses.' Australian Journal of Political Science 32(2): 237-254.

Charnock, D. and P. Ellis. 2003. 'Postmaterialism and Postmodernization in Australian Electoral Politics.' Electoral Studies (in press).

Charnock, D. and P. Ellis. 2001. 'Is One Nation really a Postmaterialist Party?' Proceedings of the 2001 Conference of the Australasian Political Studies Association. Brisbane: Griffith University/APSA.

Clarke, H. D., A. Kornberg, C. McIntyre, P. Bauer-Kaase and M. Kaase. 1999. 'The Effect of Economic Priorities on the Measurement of Value Change: New Experimental Evidence.' American Political Science Review 93(3): 637-647.

Davis, D. W. and C. Davenport. 1999. 'Assessing the Validity of the Postmaterialism Index.' American Political Science Review 93(3): 649-664.

Gibbins, J.R. and Bo Reimer. 1999. The Politics of Postmodernity. London: Sage.

Goot, M. and I. Watson. 2001. 'One Nation's Electoral Support: Where does it come from, What makes it different and How does it fit?' Australian Journal of Politics and History 47: 159-191.

Gow, D. J. 1990. 'Economic voting and postmaterialist values.' In The Greening of Australian Politics: the 1990 Federal Election, eds C. Bean, I. McAllister and J. Warhurst. Melbourne: Longman Cheshire.

Inglehart, R. 1997. Modernization and Postmodernization: Cultural, Economic, and Political Change in 43 Societies. Princeton, New Jersey: Princeton University Press. 
Charnock, David and Ellis, Peter (2003) The Structure of the Australian Party System and its Strategic Consequences, The Australian Journal of Political Science 38(3):423-443.

Inglehart, R. 1990. Culture Shift in Advanced Industrial Society. Princeton, New Jersey: Princeton University Press.

Inglehart, R. 1977. The Silent Revolution: Changing Values and Political Styles. Princeton, New Jersey: Princeton University Press.

Inglehart, R. and P. R. Abramson. 1999. 'Measuring Postmaterialism.' American Political Science Review 93(3): 665-678.

Kitschelt, H. 1995. The Radical Right in Western Europe: A Comparative Analysis. Ann Arbor: University of Michigan Press.

Kitschelt, H. 1994. The Transformation of European Social Democracy. Cambridge: Cambridge University Press.

Long, J.S. 1997. Regression Models for Categorical and Limited Dependent Variables. Thousand Oaks, CA: Sage.

McAllister, I. and C. Bean. 2000. 'The electoral politics of economic reform in Australia: the 1998 election.' Australian Journal of Political Science 35(3): 383-399.

Venables, W. and B. Ripley. 1999. Modern Applied Statistics with S-Plus 3rd ed. New York: Springer.

Warwick, P. V. 1998. 'Disputed cause, disputed effect: the postmaterialist thesis reexamined.' Public Opinion Quarterly 62(4): 583-609.

Western, M. and B. Tranter. 2001. 'Postmaterialist and Economic voting in Australia, 1990-1998.' Australian Journal of Political Science 36(3): 439-458. 
Charnock, David and Ellis, Peter (2003) The Structure of the Australian Party System and its Strategic Consequences, The Australian Journal of Political Science 38(3):423-443.

Figure 1

Postmaterialism (4-item measure) and Left-Right economic positions of Senate voters 2001

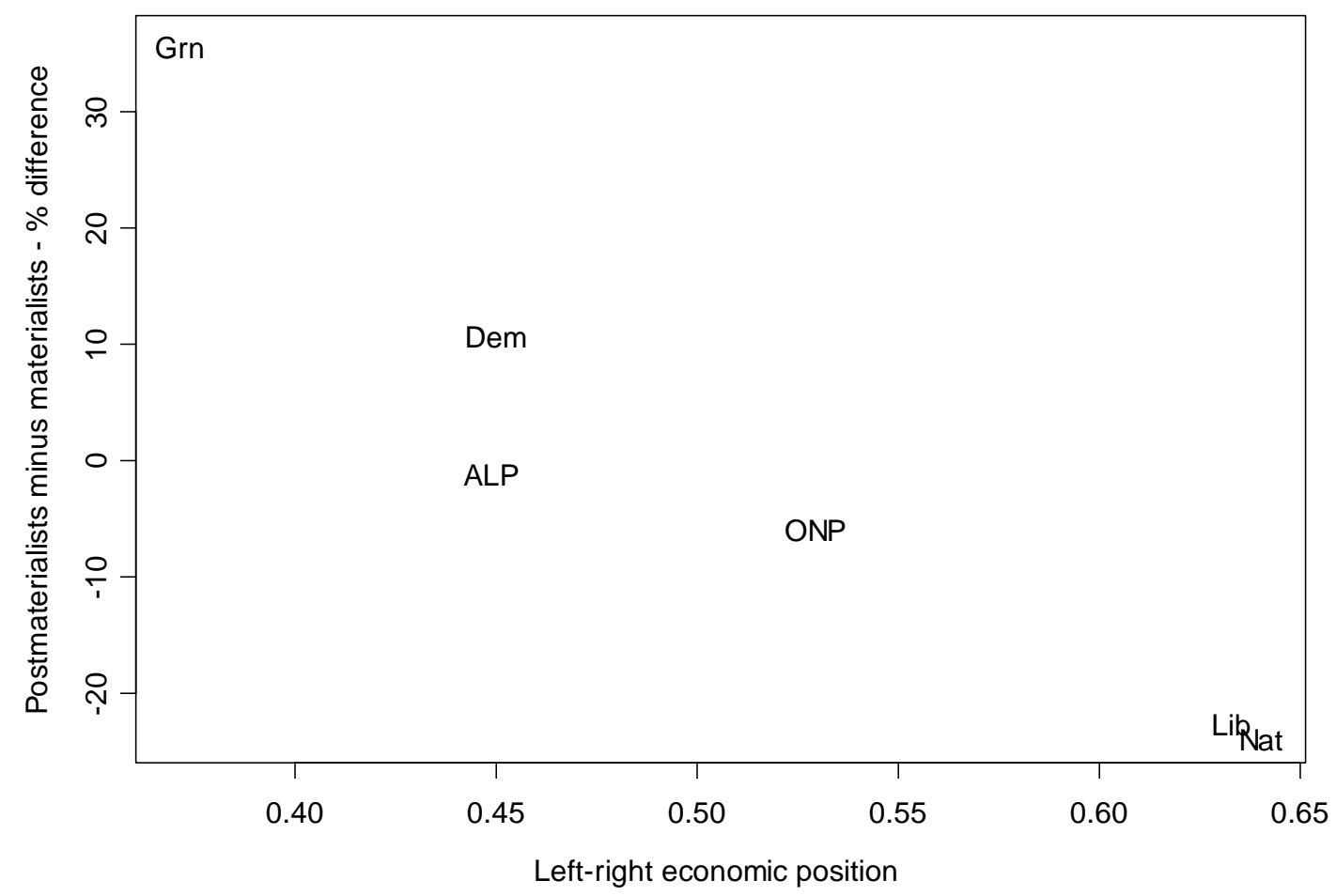


Charnock, David and Ellis, Peter (2003) The Structure of the Australian Party System and its Strategic Consequences, The Australian Journal of Political Science 38(3):423-443.

Figure 2

Postmaterialism (twelve-item measure) and Left-Right economic positions of Senate voters 2001

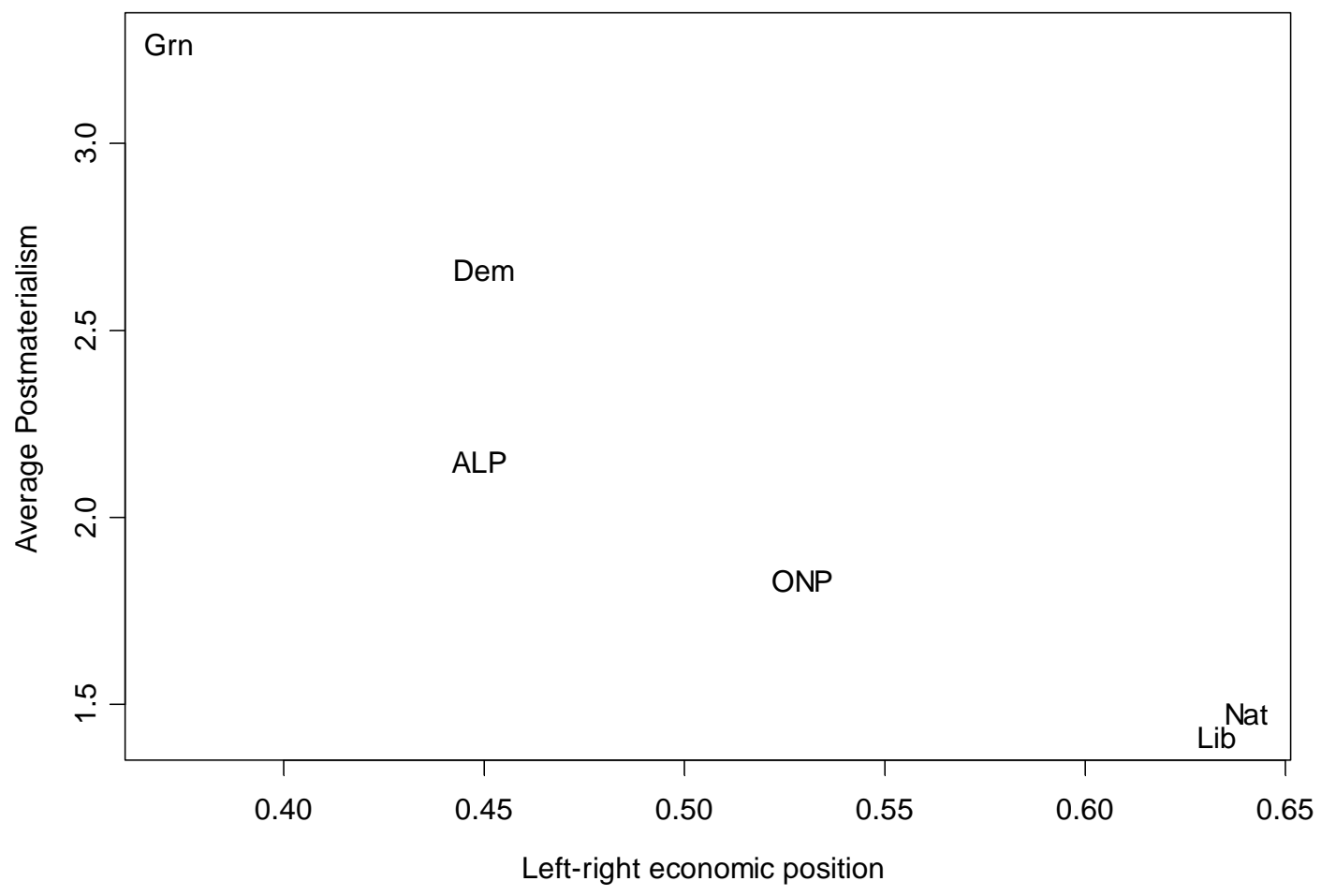


Charnock, David and Ellis, Peter (2003) The Structure of the Australian Party System and its Strategic Consequences, The Australian Journal of Political Science 38(3):423-443.

\section{Figure 3}

\section{Postmodern attitudes and Left-Right economic positions of Senate voters 2001}

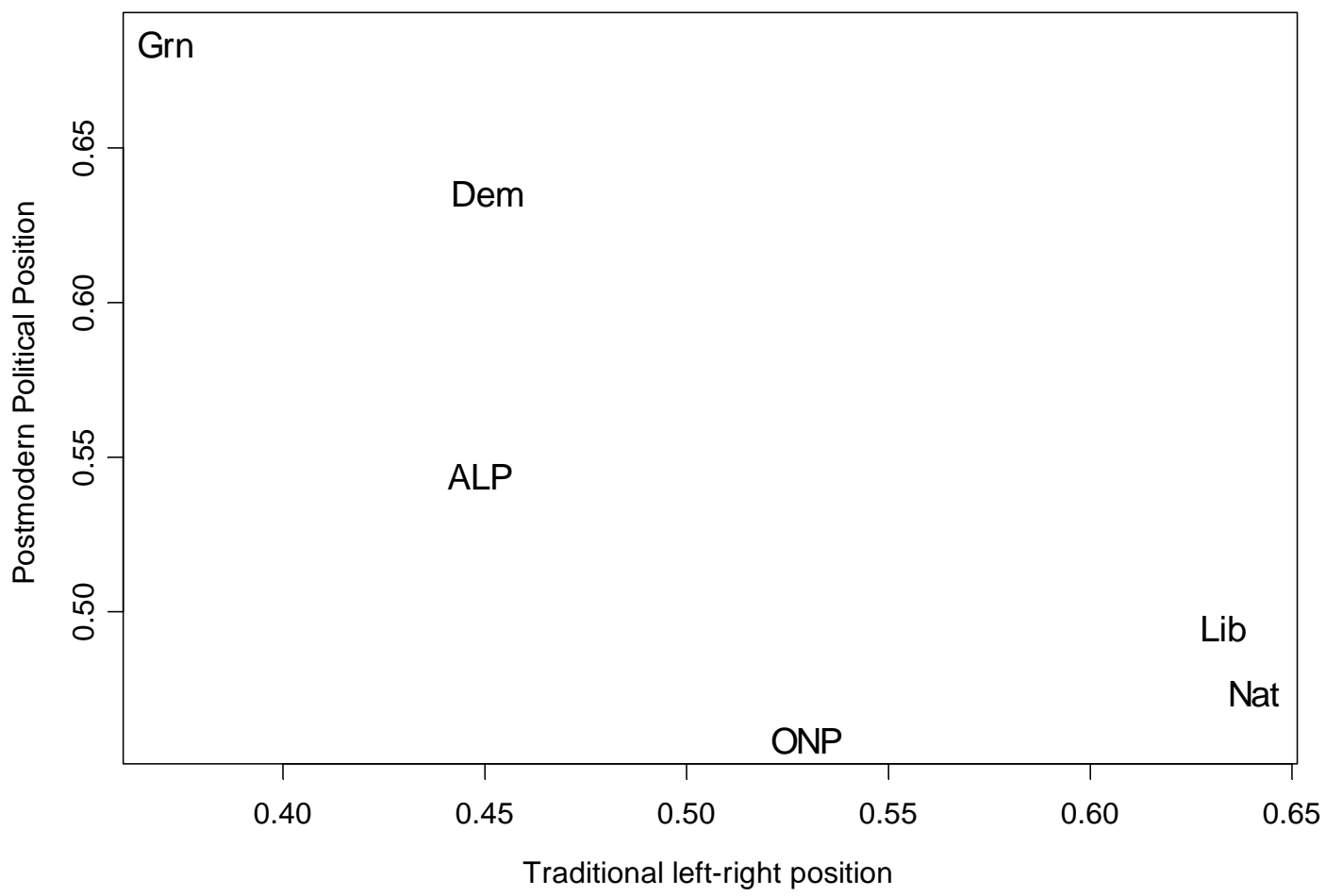

Note: The vertical axis shows the mean score of voters for each party on the combined (25-item) postmodern attitudes index, and the horizontal axis shows the mean score of each party's voters on the left-right attitudes index. 
Charnock, David and Ellis, Peter (2003) The Structure of the Australian Party System and its Strategic Consequences, The Australian Journal of Political Science 38(3):423-443.

\section{Figure 4}

\section{Mean deviations on attitude scales from Liberal Senate voters 2001}

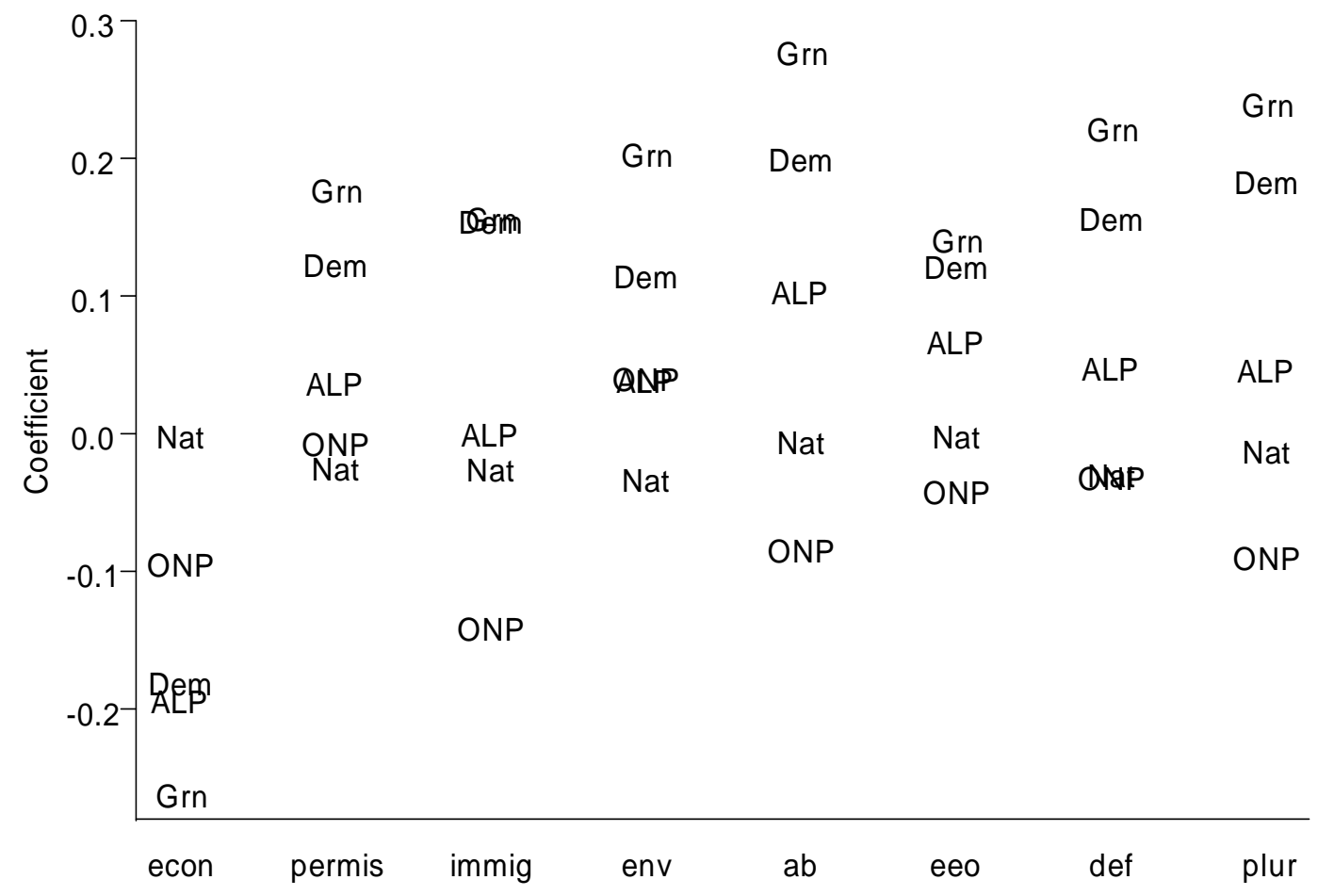

Note: the graph shows the mean difference between the scores of voters for the various parties and that of Liberal voters e.g. the average score of Democrats voters on the Aboriginal attitudes index was about 0.2 higher than that of Liberal voters. The mean scores on the IMMIG index of Green and Democrat voters are so close as to be visually indistinguishable, as also are those of ALP and ONP voters on the ENV index, and those of National and ONP voters on the DEF index. 
Charnock, David and Ellis, Peter (2003) The Structure of the Australian Party System and its Strategic Consequences, The Australian Journal of Political Science 38(3):423-443.

\section{Figure 5}

Intra-party Variations in Postmodern political and Left-Right economic

\section{Position of Senate voters 2001}
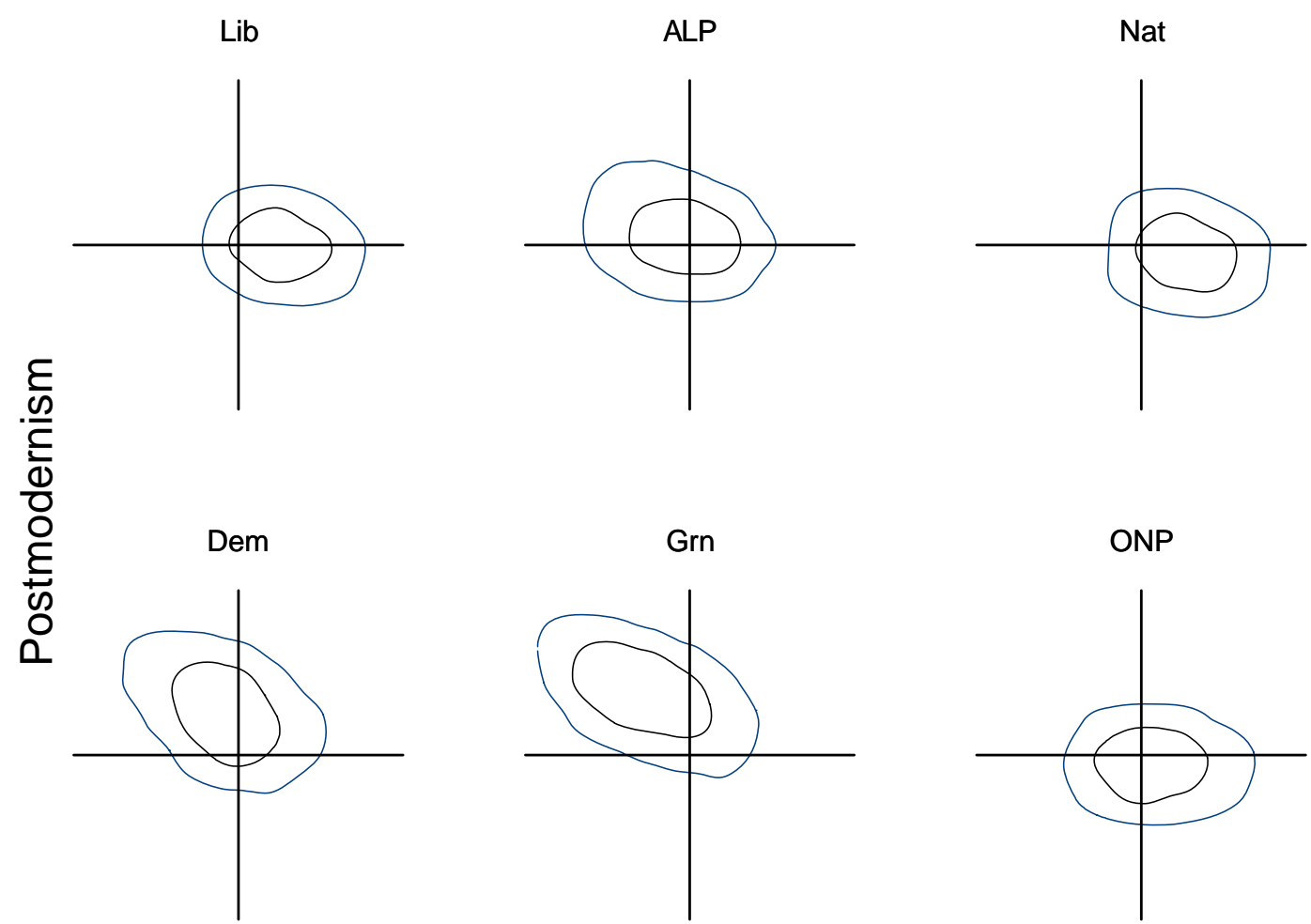

Traditional economic

Note: inner lines enclose $40 \%$ and outer lines $80 \%$ of the estimated voting population for each party 
Charnock, David and Ellis, Peter (2003) The Structure of the Australian Party System and its Strategic Consequences, The Australian Journal of Political Science 38(3):423-443.

Table 1: Null Model for 2001 Senate vote

\begin{tabular}{lr}
\hline Party & $\begin{array}{r}\text { Intercept } \\
\text { Estimate }\end{array}$ \\
\hline ALP & $-0.19^{*}(0.06)$ \\
National & $-2.23^{*}(0.12)$ \\
Democrats & $-1.44^{*}(0.09)$ \\
Greens & $-1.66^{*}(0.10)$ \\
One Nation & $-2.03^{*}(0.11)$ \\
\hline
\end{tabular}

Note: $A I C=4821.3 ;$ Deviance=4811.3; $n=1666 ;$ * significant at 0.01 level

Table 2: Model A1

\begin{tabular}{lrr}
\hline Party & $\begin{array}{r}\text { Intercept } \\
\text { Estimate }(\text { s.e.) }\end{array}$ & $\begin{array}{r}\text { Left-Right Economic } \\
\text { Estimate (s.e.) }\end{array}$ \\
\hline ALP & $4.15^{*}(0.27)$ & $-7.99^{*}(0.47)$ \\
National & $-2.25^{*}(\odot .56)$ & $0.03(0.86)$ \\
Democrats & $2.70^{*}(\odot .33)$ & $-7.52^{*}(\odot .62)$ \\
Greens & $3.64^{*}(\odot .33)$ & $-10.33^{*}(\odot .69)$ \\
One Nation & $0.42(\odot .44)$ & $-4.15^{*}(0.76)$ \\
\hline
\end{tabular}

Note: $A I C=4276 . \odot ;$ Deviance $=4256.0 ; n=1666 ;$ * significant at $\odot .01$ level

Table 3: Model A2

\begin{tabular}{|c|c|c|}
\hline Party & $\begin{array}{r}\text { Intercept } \\
\text { Estimate (s.e.) }\end{array}$ & $\begin{array}{r}\text { Postmaterialism(12-item) } \\
\text { Estimate (s.e.) }\end{array}$ \\
\hline ALP & $-1.17^{*}(0.11)$ & $0.55^{*}(0.05)$ \\
\hline National & $-2.30 *(0.21)$ & $0.05(0.11)$ \\
\hline Democrats & $-3.22^{*}(0.21)$ & $0.89^{*}(0.08)$ \\
\hline Greens & $-4.61^{*}(0.28)$ & $1.28^{*}(0.09)$ \\
\hline One Nation & $-2.57^{*}(0.21)$ & $0.33^{*}(0.10)$ \\
\hline
\end{tabular}

Note: $A I C=449 \odot . \odot ;$ Deviance=447๑.๑; $n=1666 ;$ * significant at $\odot . \odot 1$ level 
Table 4: Model A3

\begin{tabular}{|c|c|c|}
\hline Party & $\begin{array}{r}\text { Intercept } \\
\text { Estimate (s.e.) }\end{array}$ & $\begin{array}{r}\text { Postmodern attitudes } \\
\text { Estimate (s.e.) }\end{array}$ \\
\hline ALP & $-2.43^{*}(0.30)$ & $4.29^{*}(0.55)$ \\
\hline National & $-1.46 \quad(0.60)$ & $-1.58(1.21)$ \\
\hline Democrats & $-7.31^{*}(0.50)$ & $10.46^{*}(0.82)$ \\
\hline Greens & $-9.51^{*}(0.60)$ & $13.45^{*}(0.93)$ \\
\hline One Nation & $-0.46 \quad(0.54)$ & $-3.27^{*}(1.13)$ \\
\hline
\end{tabular}

Note: $A I C=4417.7 ;$ Deviance=4397.7; $n: 1666 ;$ * significant at $\odot .01$ level

Table 5: Model B1

\begin{tabular}{|c|c|c|c|}
\hline & Intercept & Left-Right & Postmaterialism \\
\hline Party & Estimate (s.e.) & Estimate (s.e.) & Estimate (s.e.) \\
\hline ALP & $3.36^{*}(0.31)$ & $-7.53^{*}(0.49)$ & $0.31^{*}(0.06)$ \\
\hline National & $-2.39 *(0.63)$ & $0.12(0.88)$ & $0.06(0.12)$ \\
\hline Democrats & $\odot .52(0.43)$ & $-6.07^{*}(0.65)$ & $\odot .70^{*}(0.08)$ \\
\hline Greens & $0.25(0.50)$ & $-8.00^{*}(0.73)$ & $0.98 *(0.10)$ \\
\hline One Nation & $-0.15(0.53)$ & $-3.83^{*}(0.79)$ & $0.23(0.10)$ \\
\hline
\end{tabular}

Note: $A I C=4139.1 ;$ Deviance=4109.1; $n=1666 ;$ * significant at 0.01 level

Table 6: Model B2

\begin{tabular}{|c|c|c|c|}
\hline Party & $\begin{array}{r}\text { Intercept } \\
\text { Estimate (s.e.) }\end{array}$ & $\begin{array}{r}\text { Left-Right } \\
\text { Estimate (s.e.) }\end{array}$ & $\begin{array}{r}\text { Postmodern } \\
\text { Estimate (s.e.) }\end{array}$ \\
\hline ALP & $3.38^{*}(0.48)$ & $-7.98^{*}(0.49)$ & $1.47(0.66)$ \\
\hline National & $-1.19(0.94)$ & $-0.26(0.88)$ & $-1.80(1.29)$ \\
\hline Democrats & $-3.68 *(0.77)$ & $-5.11^{*}(0.68)$ & $9.10 *(0.96)$ \\
\hline Greens & $-4.08^{*}(0.89)$ & $-7.03^{*}(0.79)$ & $10.57^{*}(1.09)$ \\
\hline One Nation & $3.20 *(0.77)$ & $-4.88^{*}(0.78)$ & $-4.90^{*}(1.18)$ \\
\hline
\end{tabular}

Note: $A I C=4 \odot 46.1 ;$ Deviance $=4 \odot 16.1 ; n=1666 ;$ * significant at $\odot . \odot 1$ level 
Charnock, David and Ellis, Peter (2003) The Structure of the Australian Party System and its Strategic Consequences, The Australian Journal of Political Science 38(3):423443.

Table 7: Model C

\begin{tabular}{|c|c|c|c|c|c|c|c|}
\hline & Intercept & Left-right & PERMIS & IMMIG & ENV & $\overline{A B}$ & EEO \\
\hline Party & Estimate (s.e.) & Estimate (s.e.) & Estimate (s.e.) & Estimate (s.e.) & Estimate (s.e.) & Estimate (s.e.) & Estimate (s.e.) \\
\hline ALP & $3.47^{\star \star}(0.5 \odot)$ & $-8.07^{\star *}(0.51)$ & $0.08(0.49)$ & $-1.51^{* *}(0.37)$ & $-0.36(0.36)$ & $1.61^{\star \star}(0.39)$ & $1.40^{* \star}(0.41)$ \\
\hline National & $-1.05 \quad(0.95)$ & $-0.22(\odot .90)$ & $-1.14(0.96)$ & $-0.64(0.69)$ & $-0.97 \quad(0.66)$ & $\odot .27(0.76)$ & $0.29(0.74)$ \\
\hline Democrats & $-3.46^{* *}(0.79)$ & $-4.92 * *(\odot .7 \odot)$ & $1.90 * *(0.68)$ & $1.44^{* *}(0.56)$ & $1.91^{* *}(0.58)$ & $2.28^{* *}(\odot .58)$ & $1.24^{*}(0.61)$ \\
\hline Greens & $-5.26 * *(\odot .99)$ & $-6.56 * *(0.79)$ & $2.87^{* *}(0.78)$ & $-0.15(0.63)$ & $5.09 * *(\odot .83)$ & $3.37^{* *}(\odot .67)$ & $\odot .44(0.70)$ \\
\hline One Nation & $1.95^{*}(\odot .82)$ & $-4.56 * *(0.79)$ & $0.66(0.87)$ & $-3.14^{* *}(0.66)$ & $0.67(0.63)$ & $-1.76^{*}(0.69)$ & $-0.45(0.67)$ \\
\hline
\end{tabular}

Note: $A I C=3974.5 ;$ Deviance=39๑4.5; $n=1666 ;$ * significant at $\odot .01$ level; * significant at $\odot .05$ level 